\title{
Antifibrinolytic therapy in genitourinary tract surgery
}

\author{
LENNART ANDERSSON \\ From the Department of Urology, Karolinska Sjukhuset, Stockholm, Sweden
}

Severe generalised haemorrhage associated with plasma proteolytic activity after thoracic surgery, operations for hyperplasia or carcinoma of the prostate, gastrointestinal or pancreatic resection, and other operations was reported in the early 1950s. ${ }^{1-3}$ Such plasma proteolytic activity is usually part of a disseminated intravascular coagulation syndrome. Sometimes, however, the local fibrinolytic activity in the area of the operation or trauma disturbs haemostasis and wound healing. This activity is not usually pathological but is a physiological one in different tissues and body fluids.

\section{Plasminogen activators}

Astrup and Permin ${ }^{4}$ first demonstrated an activator of plasminogen in various human and animal tissues. Albrechtsen ${ }^{5}$ reported that the prostate is one of the human tissues with the highest concentration of plasminogen activator. The distribution of this activator in the tissues was studied in more detail by Todd, ${ }^{6}$ Pandolfi, ${ }^{7}$ Nilsson and Pandolf, ${ }^{8}$ and others. A plasminogen activator in urine was first detected by Williams. ${ }^{9}$ Fibrinolytic activators have been found in other body fluids such as human milk ${ }^{10}$ and tear fluid. ${ }^{11}$

Intact haemostasis, both primary and secondary, is a prerequisite for the healing of wounds. Premature dissolution of haemostatic clots interferes with the healing process. In prostatic surgery satisfactory haemostasis is sometimes difficult to achieve and troublesome postoperative bleeding is fairly common. After prostatectomy, whether by an open approach or by transurethral resection, many blood vessels in the wall of the cavity remain open, plugged by haemostatic clots. The prostatic capsule contains abundant activators of plasminogen. The cavity is also bathed by urine which contains urokinase, a potent plasminogen activator. Both tissue activator and urokinase accelerate the dissolution of clots and consequently increase and prolong oozing haemorrhage.

\section{Antifibrinolytic drugs}

When antifibrinolytic drugs became clinically available about 20 years ago interest focused on their possible effect on urinary tract haemorrhage. It was independently reported that treatment with epsilon-aminocaproic acid (EACA) reduced bleeding after prostatectomy. ${ }^{12-14}$ Andersson ${ }^{15}$ investigated the blood loss during the first three 24-hour periods after transvesical prostatectomy in three groups each of 25 patients. In one group EACA was given in a total dose of $14 \mathrm{~g}$ over three days, in another the patients received the drug in a varying but larger dose (on average $51 \mathrm{~g}$ over three days), and in the third no antifibrinolytic drug was given. In the control group the postoperative blood loss averaged $494 \mathrm{ml}$, in the smaller-dose group it

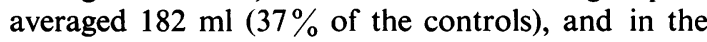
larger-dose group it averaged $91 \mathrm{ml}(18 \%$ of the controls). The operative blood loss was not influenced by the medication.

$\mathrm{McNicol}$ et al. ${ }^{13}$ reported that EACA given in a total dose of $8 \mathrm{~g}$ in the first 12 postoperative hours reduced postoperative blood loss by $50 \%$ after suprapubic prostatectomy and by $75 \%$ after transurethral resection. Vinnicombe and Shuttleworth $^{16}$ found that postoperative haemorrhage in a randomised series of patients subjected to retropubic prostatectomy was reduced to approximately onethird in patients given EACA $6 \mathrm{~g}$ in 12 hours compared with that in untreated controls.

Tranexamic acid (aminomethyl cyclohexane carboxylic acid (AMCA)) is a stronger inhibitor of plasminogen activation than EACA. In a randomised double-blind trial Hedlund ${ }^{17}$ studied the postoperative blood loss after transvesical prostatectomy in patients given AMCA in a total dose of either $6 \mathrm{~g}$ or $12 \mathrm{~g}$ or a placebo at the start of the operation and continuing for the first four postoperative days. The average postoperative blood loss in the patients given $12 \mathrm{~g}$ AMCA was $48 \%$ $(\mathrm{P}<0.01)$ and in those given $6 \mathrm{~g} \mathrm{53 \%}(\mathrm{P}<0.02)$ of the blood loss in the placebo patients. 


\section{Risk of thromboembolism}

It has been debated whether antifibrinolytic therapy increases the risk of postoperative thromboembolism. Hedlund, ${ }^{18}$ using the ${ }^{125}$ I-fibrinogen uptake test, found no significant difference in the incidence of thrombosis between the patients on AMCA and those on placebo. This corresponds with the findings of Vinnicombe and Shuttleworth ${ }^{\mathbf{1 9}}$ and Becker and Borgström, ${ }^{20}$ who used other diagnostic methods. Nevertheless, thromboembolism in patients on antifibrinolytic drugs has been described, as with all kind of prostatic surgery. In manifest phlebothrombosis antifibrinolytic treatment retards lysis of the thrombus and thus aggravates the condition. It should therefore be discontinued in patients with evidence of thromboembolism.

Aiming to reduce the fibrinolytic activity in the prostatic cavity and obviate the risk of thrombosis with systemic antifibrinolytic therapy, Vecsey, Bánkuti, and Czuczor ${ }^{21}$ and Vecsey, Bánkuti, and Pálfy ${ }^{22}$ gave AMCA intravenously during the operation and as a continuous bladder irrigation postoperatively. When a $1 \%$ solution of AMCA was used for the irrigation the 24-hour blood loss after transvesical prostatectomy was reduced from an average of $376 \mathrm{ml}$ in an untreated control group to an average of $47.4 \mathrm{ml}(13 \%)$. For prophylaxis the patients were given $500 \mathrm{ml}$ Rheomacrodex during the operation and on postoperative days 1,2 , and 3 . No cases of thromboembolism occurred.

Bleeding is a threat in prostatic surgery in patients with coagulation defects or dysfibrinogenaemia. The risk may be countered in part by antifibrinolytic therapy. ${ }^{23}$ Renal bleeding is sustained and prolonged by the fibrinolytic activity of urine. Antifibrinolytic drugs, however, should be given with the utmost caution in bleeding from the upper urinary tract because of the risk of clot retention in the kidney. ${ }^{24}$ In cases of so-called essential haematuria or haemorrhage after kidney trauma, when the bleeding is slight but protracted, antifibrinolytic treatment can be given with relative safety and often successfully. ${ }^{25}$

There is evidence that antifibrinolytic treatment reduces blood loss after dental extractions in patients with coagulation defects, ${ }^{26}$ after tonsillectomy, ${ }^{27} 28$ in severe epistaxis, ${ }^{29}$ and in some cases of upper gastrointestinal haemorrhage. ${ }^{30} 31$ Recurrent bleeding in subarachnoid haemorrhage ${ }^{32}$ and traumatic hyphaema ${ }^{33}$ are minimised by antifibrinolytic therapy.

\section{Conclusion}

Even though a number of postoperative bleeding complications may be successfully treated or pre- vented by antifibrinolytic drugs, it should be remembered that excessive bleeding after operation is mostly due to inadequate surgical haemostasis. No medication can substitute for surgical technique. Antifibrinolytic drugs are therefore complementary to surgery. Reduced bleeding from the prostatic bed aids recovery, mainly because it results in better drainage of the bladder which, in turn, lessens the risk of infection. Improved operative and postoperative care has widened the scope of prostatic surgery. In my opinion, antifibrinolytic drugs have had a significant part in this improvement.

\section{References}

${ }^{1}$ Mathey J, Daumet P, Soulier JP, Le Bolloch AG, Fayet H. Hémorrhagies graves an cours d'interventions thoraciques par incoagulabilité sanguine due à la fibrinolyse. Mem Acad Chir 1950;76:977-86.

${ }^{2}$ Ratnoff OD. Studies on a proteolytic enzyme in human plasma. VII. A fatal haemorrhagic state associated with excessive plasma proteolytic activity in a patient undergoing surgery for carcinoma of the head of the pancreas. J Clin Invest 1952;31:521-8.

${ }^{3}$ Scott EVZ, Matthews WF, Butterworth CE Jr, Frommeyer WB Jr. Abnormal plasma proteolytic activity. Surg Gynecol Obstet 1954;99:679-88.

4 Astrup T, Permin PM. Fibrinolysis in the animal organism. Nature 1947;159:681-2.

${ }^{5}$ Albrechtsen OK. The fibrinolytic activity of human tissues. Br J Haematol 1957;3:284-91.

${ }^{6}$ Todd AS. Histological localisation of fibrinolysin activator. J Pathol Bact 1959;78:281-3.

7 Pandolfi M. Studies on fibrinolysis in some tissues and in aqueous humor. Thesis Berlingska Boktryckeriet, Lund, 1969.

${ }^{8}$ Nilsson IM, Pandolfi M. Fibrinolytic response of the vascular wall. Thromb Diath Haemorrh, Suppl 40, 1970;231-42.

9 Williams JRB. The fibrinolytic activity of urine. $B r J$ Exp Pathol $1951 ; 32: 530-7$.

${ }^{10}$ Astrup T, Sterndorff I. A fibrinolytic system in human milk. Proc Soc Exp Biol Med 1953;84:605-8.

11 Storm O. Fibrinolytic activity in human tears. Scand $J$ Clin Lab Invest 1955;7:55-8.

12 Andersson L, Nilsson IM. Treatment of fibrinolytic states in prostatic disease with EACA. Proc 8th Congr Europ Soc Haematol, Vienna $1961: 452$.

${ }^{13}$ McNicol GP, Fletcher AP, Alkjaersig N, Sherry S. The use of epsilon-aminocaproic acid, a potent inhibitor of fibrinolytic activity, in the management of postoperative hematuria. J Urol 1961 ;86:829-37.

${ }^{14}$ Sack E, Spaet TH, Gentile RL, Hudson PB. Reduction of postprostatectomy bleeding by epsilon-aminocaproic acid. $N$ Engl J Med 1962;266:541-3.

15 Andersson L. Antifibrinolytic treatment with epsilonaminocaproic acid in connection with prostatectomy. Acta Chir Scand 1964;127:552-64.

${ }^{16}$ Vinnicombe J, Shuttleworth KED. Aminocaproic acid in the control of haemorrhage after prostatectomy. 
A controlled trial. Lancet 1966;1:230-2.

17 Hedlund PO. Antifibrinolytic therapy with cyklokapron in connection with prostatectomy. A double-blind study. Scand J Urol Nephrol 1969;3:177-82.

18 Hedlund PO. Postoperative venous thrombosis in benign prostatic disease. Scand J Urol Nephrol 1975; Suppl 27:46.

19 Vinnicombe J, Shuttleworth KED. Aminocaproic acid in the control of haemorrhage after prostatectomy. Safety of aminocaproic acid-a controlled trial. Lancet 1966;1:232-4.

${ }^{20}$ Becker J, Borgström S. Incidence of thrombosis associated with epsilon-aminocaproic acid administration and with combined epsilon-aminocaproic acid and subcutaneous heparin therapy. Acta Chir Scand 1968;134:343-9.

${ }^{21}$ Vecsey D, Bánkuti P, Czuczor H. Über die lokale Behandlung der nach Prostatektomie auftretenden Blutungen mit Anti-fibrinolytika. Z Urol 1967;60: 831-5.

${ }^{22}$ Vecsey D, Bánkuti P, Pálfy A. Blutungsprophylaxe nach Prostatektomie mit AMCA. Med Welt 1977; 28:1100-2.

${ }^{23}$ Forman WB, Kraus J. Transurethral resection in a patient with a dysfibrinogen: fibrinogen Cleveland I. J Urol 1977;118:885.

${ }^{24}$ Lingårdh G, Andersson L. Clot retention in the kidney as a probable cause of anuria during treatment of haematuria with epsilon-aminocaproic acid. Acta Med Scand 1966;180:469-73.

${ }^{25}$ Andersson, L. Treatment of so-called essential haematuria with fibrinolytic inhibitor (epsilonaminocaproic acid). Acta Chir Scand 1962;124: 355-64.

${ }^{26}$ Forbes CD, Barr RD, Reid G, et al. Tranexamic acid in control of haemorrhage after dental extraction in haemophilia and Christmas disease. $\mathrm{Br} \mathrm{Med} J$ 1972;ii :311-3.

${ }^{27}$ Castelli G, Vogt E. Der Erfolg einer antifibrinolytischen Behandlung mit Tranexamsäure zur Reduktion des Blutverlustes während und nach Tonsillektomien. Schweiz Med Wochenschr 1977;107:780-4.

${ }^{28}$ Verstraete M, Tyberghein J, De Greef Y, Daems L, van Hoof A. Double-blind trials with ethamsylate, batroxobin or tranexamic acid on blood loss after adenotonsillectomy. Acta Clin Belg 1977;32:136-41.

${ }^{29}$ Petruson B. A double-blind study to evaluate the effect on epistaxis with oral administration of the antifibrinolytic drug tranexamic acid (Cyklokapron). Acta Otolaryngol [Suppl] (Stockh) 1974;317:57-61.

${ }^{30}$ Nilsson IM, Bergentz SE, Hedner U, Kullenberg K. Gastric fibrinolysis. Thromb Diath Haemorrh 1975; 34:409-18.

${ }^{31}$ Biggs JC, Hugh TB, Dodds AJ. Tranexamic acid and upper gastrointestinal haemorrhage - a double-blind trial. Gut 1976;17:729-34.

${ }^{32}$ Tovi $D$. The use of antifibrinolytic drugs to prevent early recurrent aneurysmal subarachnoid haemorrhage. Acta Neurol Scand 1973;49:163-75.

${ }^{33}$ Bramsen T. Traumatic hyphaema treated with the antifibrinolytic drug tranexamic acid II. Acta Ophtalmol (Kbh) 1977;55:616-20. 